\title{
THE VALUE OF KNOWLEDGE IN THE MALAY MIND: A COGNITIVE SEMANTIC ANALYSIS
}

\author{
Khazriyati Salehuddin* \\ Faculty of Social Sciences and Humanities, Universiti Kebangsaan Malaysia, \\ 43600 UKM Bangi, Selangor, Malaysia \\ e-mail: khazudin@ukm.edu.my
}

Published online: 15 July 2018

To cite this article: Salehuddin, K. 2018. The value of KNOWLEDGE in the Malay mind: A cognitive semantic analysis. International Journal of Asia Pacific Studies 14 (2): 39-59, https://doi.org/10.21315/ijaps2018.14.2.2

To link to this article: https://doi.org/10.21315/ijaps2018.14.2.2

\begin{abstract}
KNOWLEDGE is a universal concept that permeates all nations and civilisations. Like any other concepts, KNOWLEDGE is also manifested in the form of figurative expressions. Previous studies have shown that the figurative expressions used in a particular language are closely related to the culture in which that particular language is used; this phenomenon is consistent with the linguistic relativity theory. In addition, studies in cognitive semantics have shown that the construction of figurative expressions occurs systematically in the minds of its users. Thus, this paper describes how KNOWLEDGE is represented in the Malay mind and how the concept is valued by the Malay speech community using the cognitive semantic approach. Specifically, this paper illustrates how KNOWLEDGE is valued by the Malay speech community through expressions related to KNOWLEDGE via the use of three Idealised Cognitive Models, namely conceptual metaphors, metonymies and kinaesthetic image schemas. Results highlight the manifestation of KNOWLEDGE figuratively in a variety of ways and this illustrates the manner the concept is perceived by the Malay speech community, i.e., KNOWLEDGE is something big and is a source of light; hence, knowledge has to be sought in a proactive manner and that seeking knowledge is a life-long process. The findings of this study suggest that KNOWLEDGE can be discussed using the more universal conceptual metaphor THE MIND IS THE BODY, with different manifestations of the conceptual metaphor. This suggests that the way
\end{abstract}


human beings think is rather universal; and this is the factor that unites mankind all over the world.

Keywords: Cognitive semantics, conceptual metaphor, KNOWLEDGE, Malay cognition, metonymy

\section{INTRODUCTION}

Civilisations and their people exist and develop because of knowledge. Knowledge is an abstract concept that cannot be measured in any way, except through its manifestations. This is because KNOWLEDGE, like TIME, LOVE and POWER, cannot be referred to by any form of concrete references. Because of the abstract nature of KNOWLEDGE, one of the ways to express the concept is through the use of metaphors (Adriessen and Van Den Boom 2009). Using the cognitive semantic approach, Adriessen and Van Den Boom (2009) have shown that the conceptual metaphor KNOWLEDGE IS A JOURNEY can be used to highlight the dynamic, contextual and social features of KNOWLEDGE.

Nevertheless, the cognitive semantic analysis conducted by Andriessen and Van Den Boom (2009) was done only on the English language. It is a wellknown fact that despite the fact that abstract concepts (e.g., LIFE) are generally universal in nature, the manifestations of concepts vary in different languages, depending on the cultures in which the languages are spoken. For example, although LIFE is considered as A JOURNEY by the speech communities in the United States and Hungary, the concept is manifested by these communities differently. The Americans, for example, see LIFE as "having to keep moving" whereas the Hungarians view LIFE as "a big journey" (Kövecses 2007). Although the common metaphor THE MIND IS THE BODY is used universally, with regard to the concept of KNOWLEDGE, the concept is manifested in different forms, namely in the form of SEEING among the speakers of Indo-European languages (Sweetser 1990) and in HEARING among the speakers of Australian languages (Kövecses 2007).

As previously shown, the metaphors that are used in a particular language is closely related to the culture in which that particular language is used; and this phenomenon is consistent with the linguistic relativity theory (Boroditsky 2012). However, according to Lakoff and Johnson (1980) in their cognitive linguistics framework, metaphors do not occur in a particular language; rather, it occurs in the minds of the humans. In other words, Lakoff and Johnson (1980) highlight the idea that humans understand the world (or the concepts that exist in this life) through metaphors; and this contradicts with the notion that humans only use metaphors to explain concepts that we understand. 
A metaphor is a form of figurative expression. From the perspective of cognitive semantics, figurative expressions generally refer to the use of language whose meaning is not the same with its literal meaning (Gibbs and Colston 2012) that a "semantic tension" (or in other words, discrepancies in terms of meaning) is felt because of the mismatch that occurs in the minds of its users (see Taverniers (2006) for a further explanation on "semantic tension"). Usually, a figurative expression is used as an approach to convey a message more effectively. From the perspective of cognitive semantics, the figurative expressions that we use are very closely linked with the past experiences which we store in our minds (Black 1972).

Studies in cognitive semantics show that the use of figurative expressions does not occur randomly. As a matter of fact, the construction of figurative expressions occurs systematically in the minds of its users. The motivation (i.e., the reason) why a particular object (i.e., the source domain) is used to describe a particular abstract concept (i.e., the target domain) through figurative expressions can be appreciated if the system that makes up both objects (as the source domain and the target domain respectively) is examined carefully (Kövecses and Szabó 1996). For example, the word "bullet" is often used in the place of the word "staple" not because of the physical features of the two; as a matter of fact, the physical features of a bullet show no resemblance at all with those of a staple. Yet, "bullet" is used as a metaphorical expression for the word "staple" because of the system that makes both objects fully functional. Like a "bullet," a "staple" needs the presence of another tool for it to function; and like a "bullet" too, a "staple" needs to be triggered, and a special mechanism that acts like the trigger of a rifle has to be present for it to function. Hence, despite the non-identical physical qualities between a "bullet" (the source domain) and a "staple" (the target domain), the system that makes both objects fully functional has become the motivation that allows speakers of the English language to use them interchangeably to refer to this piece of stationery (Salehuddin 2001). The characteristics beyond the physical features of a "bullet" is indeed an example of what Black (1972: 38) called "system of things." "System of things" has become an important aspect in the selection and the formation of metaphors among users of particular languages.

\section{METAPHORS IN THE MALAY LANGUAGE}

The "system of things" mentioned earlier is also found in the formation of Malay metaphors. The Malay name for the "ring finger" (i.e., jari manis, which is literally translated as "sweet finger") did not obviously get its name 
because of its taste. Instead, the name of the finger could be created following the similarities between the facial expression of those who receive rings in their ring finger (e.g., at weddings) and the facial expression of those who consume something sweet (Salehuddin 2001). Like in other languages, the notion of "system of things" is also applicable in the formation of Malay euphemisms in order to mitigate the undesirable effect that might be offensive to the speakers especially in discussing sensitive topics such as death (Abdul Wahab et al. 2016a, 2016b). The expressions meninggal dunia (literally "leave the world") and pulang ke rahmatullah (literally "return to God's mercy") are used in place of mati ("died") because of the similarities that exist within the "system of things" of the unpleasant expressions and their respective mitigated expressions. Previous studies conducted on Malay and English idioms (e.g., Salehuddin 2007) show that idioms and proverbs can be used to express concepts that are abstract such as POWER using the cognitive semantic approach. The use of the idiom orang atas (which literally means "people at the top"), for example, is widely used in the Malay language to refer to "the authority" or "the one in power" through the hierarchical image schema (Salehuddin 2000). Like POWER, KNOWLEDGE is a universal concept; yet, as indicated earlier, KNOWLEDGE is manifested differently across different languages. How then, is KNOWLEDGE manifested in the Malay language?

\section{KNOWLEDGE IN THE MALAY LANGUAGE}

The word "knowledge" is known in the Malay language as ilmu; a word that is borrowed from the Arabic word الْفُمِ (al-ilmi). Apart from this word, the word pengetahuan is also used to refer to the same notion. Knowledge is an invaluable asset to human beings and its importance is emphasised through the first revelation to the Prophet Muhammad [p.b.u.h.], which is translated as "Read!" (al-Qur'an 96: 1). Knowledge is so important to the Muslims that seeking knowledge is made obligatory to them in a hadith. The translation of the hadith reads: From Anas bin Malik r.a., he narrated: Rasulullah [p.b.u.h.] said: "Seeking knowledge is obligatory upon every Muslim" (al-Tirmidhi, Hadith 74, Islamawarness.net n.d.).

In the Malaysian context, Malay and Islam are usually regarded as inseparable. In fact, Article 160 in The Federal Constitution (2010: 153), a "Malay" is defined as "a person who professes the religion of Islam, habitually speaks the Malay language, conforms to Malay custom." Therefore, it is not surprising why the ways certain issues and concepts are viewed by the Malays are similar to the teachings and practices of Islam; and this includes 
the prayers and supplications said by the Malays. As a matter of fact, the obligatory prayers are done entirely in Arabic by all Muslims regardless of their mother tongue; even some of the supplications are done in Arabic as well. This is also why KNOWLEDGE forms the backbone of the lifestyles of the Malays and because of this, the manifestations of KNOWLEDGE permeate the Malay language. Although KNOWLEDGE is abstract in nature, with regard to the Malay language, KNOWLEDGE is not manifested in its metaphorical forms all the time. As a matter of fact, the word ilmu is prevalent in the language along with the metaphorical manifestations of KNOWLEDGE because of its importance to the Malay community.

The current study discusses how KNOWLEDGE is valued by the Malays through various Malay expressions related to KNOWLEDGE. All discussions are done using conceptual metaphors as the main Idealised Cognitive Model along with kinaesthetic image schema and metonymy.

\section{IDEALISED COGNITIVE MODELS}

Idealised Cognitive Models (henceforth, ICMs) refer to the manner humans arrange their knowledge and expriences so as to enable them to give meaning and to understand certain concepts. Three of the ICMs that are relevant in this study are Conceptual metaphors, Metonymies and Kinaesthetic Image Schema.

Conceptual metaphors refer to the cognitive mechanisms used by human beings to understand concepts that are abstract (i.e., the target domain) using concrete entities (i.e., the source domain) (Kövecses and Szabó 1996). Conceptual metaphors have been found to be used in Malay figurative expressions. To illustrate, in the Malay proverb air dicincing tak akan putus (which literally means "water will not stop flowing even when it is minced"), water is used as the source domain (i.e., the entity that is concrete and easily perceived) to describe familial relationship, known as the target domain (i.e., the entity that is to be understood). The property of water (that it cannot be minced), is "carried over" to "familial relationship" through the conceptual metaphor to illustrate the power of familial relationships to the Malays: that the family institution will stand tall despite the many forms of challenges that the family institution encounters (Salehuddin 2000). Hence, in this context, the conceptual metaphor FAMILIAL RELATIONSHIP IS WATER has been used in the formation of the Malay proverb. 
Metonymy is the other type of ICM that is used in understanding certain concepts. It has a "referring function" as it describes entities that are abstract through entities that are more concrete. For example, the Petronas Twin Towers have always been used in the mass media to refer to the advancement of Malaysia; hence, in this case, the metonymy THE PETRONAS TWIN TOWERS STAND FOR MALAYSIA'S ADVANCEMENT applies.

Kinaesthetic Image Schema, on the other hand, refers to the images that human beings store in their mind to enable them to understand and explain certain concepts. These images include those that are visual, auditory, tactile, olfactory, gustatory and other kinds of experiences that are related to bodily position, weight, movement of muscles, tendons and joints, etc. Human beings store tens of thousands of these images in their mind. Although the experiences of individuals are unique, it is these images that human beings store in their mind that enable them to understand one and the other. Among the famous Kinaesthetic Image Schemas are the HIERARCHICAL (TOP-DOWN) IMAGE SCHEMAS, THE SIZE (BIG-SMALL) IMAGE SCHEMAS, THE FRONT-BACK IMAGE SCHEMA and THE DISTANCE (NEAR-FAR) IMAGE SCHEMAS. All the three ICMs mentioned above can either be used individually or be used along with one or two other ICMs - depending on how the figurative expressions are formed.

\section{METHOD}

This study is a corpus-based qualitative analysis of expressions related to KNOWLEDGE. Figurative expressions on KNOWLEDGE were collected from two main sources namely Seri Bahasa: Sirih Pinang Warisan Budaya Melayu (n.d.) and Kamus Simpulan Bahasa Melayu (1996). The figurative expressions from these two sources were scrutinised, and those expressions that describe KNOWLEDGE were selected. The identification of figurative expressions that describe KNOWLEDGE was not only done by looking for words that collocate with ilmu and pengetahuan per se; as a matter of fact, words that collocate with akal ("sense"), fikiran ("thoughts"), otak ("brain"), dada ("chest") and hati ("heart"), which are also used to refer to KNOWLEDGE as they are semantically related to ilmu through semantic extension, were also scrutinised.

Once the figurative expressions were identified, they were presented at a round table seminar on Bahasa dan Kognitif Penutur (Language and the Cognition of Its Speakers) at the Institute of the Malay World and Civilisation (ATMA), Universiti Kebangsaan Malaysia in September 2015, for verification by experts in the field of the Malay language who were also conducting studies on various aspects of figurative expressions and the cognition of those 
who use them. Once the list was finalised, the Dewan Bahasa dan Pustaka (henceforth, DBP) Corpus was used to look for instances of the selected figurative expressions. DBP is a statutory body that is in charge of preserving and promoting the Malay language, and one of it is through its portal, Pusat Rujukan Persuratan Melayu (henceforth, PRPM). This 107 million-word corpus (Mohd Fadzli bin Tajuid, DPB Officer, 2017, pers. comm.) consists of words taken from 115,530 newspapers, 550 books, 1,371 magazines, 583 literary texts and 127 working papers. The entire corpus was used to generate the frequency and concordances of the selected expressions. Therefore, unless stated otherwise, all the instances shown in this study were obtained from the DBP Corpus through PRPM. The portal was also used to verify the correct usage of the Malay language as well as the collocations and the concordances of expressions related to ilmu and/or pengetahuan.

The figurative expressions selected were later analysed from the cognitive semantic perspective and subsequently categorised into the different ICMs that are used to showcase how KNOWLEDGE is valued by the Malays. The following section discusses how KNOWLEDGE is valued by the speakers of Malay through the use of the ICMs, with conceptual metaphor as the main ICM to be discussed here.

\section{THE VALUE OF KNOWLEDGE TO THE MALAYS}

KNOWLEDGE is an abstract concept; hence, the concept is widely manifested in the form of figurative expressions in the Malay language. However, this does not mean that the word ilmu and its synonym, pengetahuan, are not used in Malay in their literal sense. As a matter of fact, ilmu and pengetahuan (which are sometimes used in the form of compound noun ilmu pengetahuan probably for emphasis purposes to reflect the momentousness of knowledge to the Malays) are widely used in the Malay spoken and written discourse (i.e., 40,123 instances of ilmu, 24,635 instances of pengetahuan and more than 5,000 instances of ilmu pengetahuan in the DBP Corpus). Our experience tells us that knowledgeable people are those who are full of ideas, are always thinking; and whatever ideas that they have always make sense. "Ideas" and "thoughts" are related to the "brain" as the act of generating ideas and thinking are known to be done in the brain.

Apart from the brain, the Malays believe that the "heart" is also an organ that is involved in thinking (Salehuddin and Maros 2004). The literal translation of "heart" in Malay is jantung, an organ that pumps blood through the entire circulatory system; however, in metaphorical sense, the "heart" is 
always translated as hati. The expression "heart broken" is always translated as patah hati and never as "patah jantung. Similarly, "kind hearted" is always translated as berhati mulia and never "berjantung mulia. In the translation of the Qur'an too, the "heart," (i.e., قلب) in "whose hearts are hardened" (al-Hajj, 22: 53) is translated into Malay as hatinya keras membatu. Even when expressing expressions such as panas hati (literally, "hot liver" to mean "angry"), more often than not, the person uttering such an expression tends to caress the region of the body where the heart is located, and not where the liver is, to cool down his anger. According to Goddard (2008):

Hati is broader and more holistic in its scope than heart, combining thinking and wanting, as well as feeling, especially in relation to other people, ...there is a moral ambivalence to the hati, which is seen as a potential source of wrong-doing and error, as well as morally correct actions. Its relation to the physical body-part (the liver) is also different in some ways to that displays by the English word heart ...the Malay hati is more cognitive and more dynamic than the heart. Memories and thoughts, for example, can be located in the hati, and there are a number of fixed expressions which are best rendered into English with mind, rather than with heart (Goddard 2008: 88).

In addition to heart, the Malay word for "chest" ( $d a d a)$ is also perceived as the part of the body that is involved in thinking. This is due to the fact that the chest is where the heart is located. Hence, the expression ilmu di dada ("knowledge at the chest") is commonplace in both the spoken and written discourse of Malay. Another Malay word that is closely related to the word ilmu is bakat ("talent"), because talent can be improved by an increase in knowledge.

KNOWLEDGE is undoubtedly valuable to the Malays and this is manifested in the figurative and prosaic expressions in the language. To the Malays, KNOWLEDGE is very big. The size of knowledge is indescribable (and infinite); that the knowledge a person has, if is being compared to the knowledge of his Creator, is merely like the size of a drop of water in the vast seven oceans. Such a description is evident in the holy Qur'an (al-Kahf 18: 109), and the translation of the verse is as follows: "Say (O Muhammad [p.b.u.h] to mankind): "If the sea were ink for (writing) the Words of my Lord, surely, the sea would be exhausted before the Words of my Lord would be finished, even if We brought (another sea) like it for its aid" (al-Qur'an 18: 109).

"Big" refers to the size of objects; big objects are "not small" from the perspective of their width, length, heights, breadths and depths. From the 
cognitive semantic perspective, "big" is related to the SIZE IMAGE SCHEMA. Our experience on the images that we store in our cognition allows us to understand that bigger objects have larger width, length, height, breadth and depth than smaller objects. For example, Box A in Figure 1 is perceived as bigger than Box B as the former has larger width, length, height, breadth and depth compared to the latter.

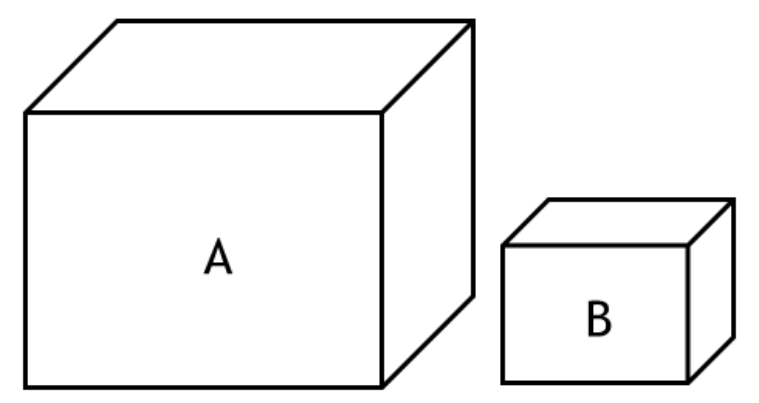

Figure 1: Different box sizes to illustrate the Size Image Schema.

The use of the conceptual metaphor KNOWLEDGE IS BIG is evident in Malay idioms, for examples:

\begin{tabular}{|c|c|c|c|c|c|c|}
\hline $\begin{array}{l}\text { Tuah } \\
\text { Tuah }\end{array}$ & $\begin{array}{l}\text { ialah } \\
\text { is }\end{array}$ & $\begin{array}{l}\text { sa-orang } \\
\text { a person }\end{array}$ & $\begin{array}{l}\text { yang } \\
\text { that }\end{array}$ & $\begin{array}{l}\text { panjang akal } \\
\text { long sense }\end{array}$ & $\begin{array}{l}d a n \\
\text { and }\end{array}$ & $\begin{array}{l}\text { pintar. } \\
\text { intelligent. }\end{array}$ \\
\hline \multicolumn{7}{|c|}{ "Tuah is far-sighted and intelligent." } \\
\hline Lagi & $\begin{array}{l}\text { banyak } \\
\text { bahasa }\end{array}$ & $\begin{array}{l}\text { yang kita } \\
\text { tahu, }\end{array}$ & lagi & $\begin{array}{l}\text { luas } \\
\text { pengetahuan }\end{array}$ & kita, & fikirku. \\
\hline More & $\begin{array}{l}\text { many } \\
\text { language }\end{array}$ & $\begin{array}{l}\text { that we } \\
\text { know }\end{array}$ & more & $\begin{array}{l}\text { wide } \\
\text { knowledge }\end{array}$ & we & I think. \\
\hline
\end{tabular}

"The more languages we know, the more knowledgeable we are, I think."

\begin{tabular}{|c|c|c|c|c|c|c|}
\hline Islam & $\begin{array}{l}\text { galak } \\
\text { ummah }\end{array}$ & $\frac{\text { dalami }}{\text { ilmu }}$ & falak & untuk & kepentingan & mereka. \\
\hline Islam & $\begin{array}{l}\text { encourage } \\
\text { people }\end{array}$ & $\begin{array}{l}\text { to deepen } \\
\text { knowledge }\end{array}$ & astronomy & for & benefit & they. \\
\hline
\end{tabular}

"Islam encourages its people to deepen their knowledge in astronomy for their benefit."

Example 1 is an instance of the conceptual metaphor KNOWLEDGE IS BIG through the word panjang. In the Malay language, a person who is panjang akal (literally, "long sense") is a person who can think well and is able to make good judgements in decision-making and performing actions. For a person to be able to make good judgements, he/she needs to be knowledgeable so that he/she can consider the pros and cons of the decisions and actions he/she makes. 
Based on our experience and knowledge about objects, the word panjang ("long") is very closely related to besar ("big"). Bigger objects have longer perimeters than smaller objects; hence, a person who possesses "large" size of knowledge is regarded as a person who is panjang akal ("intelligent").

Our encyclopedic knowledge also helps us to understand that entities that are bigger always have larger dimensions (length, width, depth/height). For example, a big car has more length, width and height than a small car. As a matter of fact, a car with bigger dimensions is always seen as being more "spacious" (luas) than a car with smaller dimensions. Our understanding of KNOWLEDGE is that a person who possesses a large amount of knowledge will most of the time be seen as having a bigger dimension of knowledge. Hence, the expressions luas pengetahuan in Example 2 refers to the characteristics of a knowledgeable person.

Bigger objects usually have more depth than smaller objects. This is because the depth of objects is closely related to the volume of the entity in question (volume $=$ length $\times$ width $\times$ depth). For example, deep oceans have larger volumes of water in comparison to shallow seas because deep oceans have more depth than shallow seas. Such encyclopaedic knowledge can be carried over to our experience on KNOWLEDGE. Individuals with deeper knowledge in a particular field are often regarded as scholars in that field (i.e., specialists in a given branch of knowledge). By definition, "depth" refers to "the extent, measurement, or dimension downward, backward, or inward" (The Free Dictionary 2003). The larger the distance between the top and the bottom (for downward, hence, deeper), the front and the back (for backward, hence, longer), and the outer and the inner surface (for inward, hence, wider), the bigger the volume the entity has. Therefore, the process of dalami ilmu ("deepening knowledge") that a person goes through in Example 3 suggests the huge size of KNOWLEDGE to the Malays.

The conceptual metaphor KNOWLEDGE IS BIG can also be found in a proverb, as in the following:
4. Kalau
kail
panjang
sejengkal,
jangan lautan
hendak
diduga.
If
fishing rod long
a span
don't ocean
want to
challenge.
"If your fishing rod is just a span in length, don't try to fish in the ocean."

In the first part of Example 4, kail ("fishing rod") is used as a metaphor through the metonymy FISHING ROD STANDS FOR A TOOL TO OBTAIN KNOWLEDGE. The tool, however, is regarded as small (panjang sejengkal) through the use of the metonymy A SPAN STANDS FOR SMALL. In the second part of Example 4, lautan ("ocean") is used as a metaphor through the conceptual metaphor 
VAST KNOWLEDGE IS OCEAN; hence, the metonymy THE OCEAN STANDS FOR INDIVIDUALS WITH VAST KNOWLEDGE underlies this proverb. These arguments are clearly derived from the conceptual metaphor KNOWLEDGE IS BIG; and the ICMs are aptly used in this proverb to advise the Malays not to challenge those who are more knowledgeable than them (via lautan) if the knowledge they possess is limited (via kail panjang sejengkal).

"Big" coexists with "small" as "small" and "big" are complementary antonyms. Smaller objects have smaller width, length, height, breadth and depth than bigger objects. Hence, words such as "narrow" and "shallow" refer to the idea of "smallness" from the perspective of width, length, height, breadth and depth. Some of these ideas of smallness are also used in Malay proverbs to mean "difficult to understand" or "rather unintelligent" (Kamus Dewan 2000). This can be seen in Examples 5 and 6 to refer to someone who is not knowledgeable or lacks of intelligence.

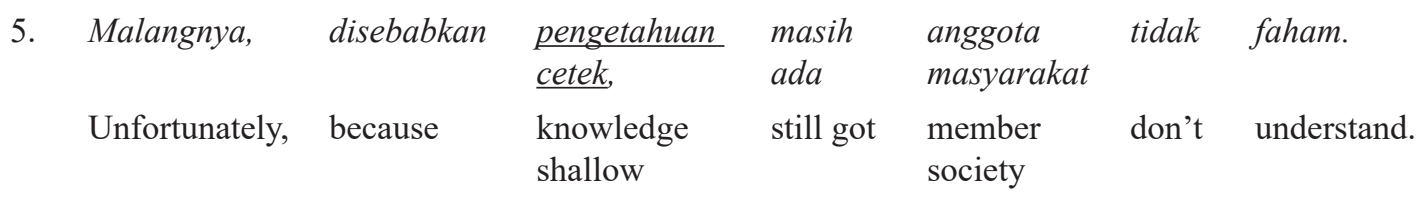

"Unfortunately, because of their lack of knowledge, there are still those who don't understand."

$\begin{array}{lllllll}\text { 6. Ketaksuban } & \text { itu } & \text { juga } & \text { mereka } & \text { sempit } \\ \text { membuat } & \text { menjadidegil, } & \text { fikiran } & \begin{array}{l}\text { mendengar } \\ \text { enggan }\end{array} & \begin{array}{l}\text { nasihat } \\ \text { Obsession }\end{array} \\ \text { the } & \text { also make } & \begin{array}{l}\text { they become } \\ \text { obstinate }\end{array} & \begin{array}{l}\text { narrow } \\ \text { thinking }\end{array} & \begin{array}{l}\text { and refuse } \\ \text { advice. }\end{array}\end{array}$

"Their obsession makes them obstinate, narrow minded; they refuse to listen to advice."

Apart from perceiving KNOWLEDGE as a big entity, KNOWLEDGE is also perceived by the Malays as "light," especially because their ways of life is in accordance to the teachings and practices of Islam. The Qur'an is regarded as the source of knowledge for mankind and this is done through the conceptual metaphor THE QUR'AN IS LIGHT. This is manifested in various contexts. For example, at the completion of the recitation of the Qur'an, a supplication is made and its translation is as follows: "make the Qur'an my guide as well as a source of light, guidance and grace for me" (Everymuslim.net n.d.). Since the Qur'an can be equated with knowledge, and that the conceptual metaphor THE QUR'AN IS LIGHT, the conceptual metaphor KNOWLEDGE IS LIGHT can be derived.

Among the Malays, such a conceptual metaphor is prevalent in their lives as knowledge is often regarded as pelita hidup ("lamp of life") (Bahasa Melayu SPM 2012). The expression ilmu itu pelita hidup (literally, "knowledge is lamp of life") is manifested in various forms and among them in the form 
of a poster (Senilukis101 n. d.). From the conceptual metaphor KNOWLEDGE IS LIGHT, Malay idioms such as terang hati ("bright heart") and terang fikiran ("bright mind") which refer to a person who can easily understand what is being taught, and terang akal ("bright sense") which refers to a clever and intelligent person (Kamus Dewan 2000: 1528) are derived. The Malay idiom terang hati has an additional ICM in its creation, namely the metonymy THE HEART STANDS FOR THOUGHTS.

In the daily supplications of the Malays, the following invocations are also made so that the process of acquiring new knowledge can be done easily. The translation of the supplications reads: "O God, please bring me out of the darkness of doubt and favour me with the light of comprehension" and "O Allah let my heart be filled with light and sight and understanding and knowledge, verily you control everything" (Duas.org n. d.). These invocations also support the conceptual metaphor KNOWLEDGE IS LIGHT and this ICM permeates in the Malay language, among others, in the form of idioms. For example:

$\begin{array}{llllll}\text { 7. Dia } & \text { teranghati } & \text { walaupun } & \text { tidak } & \text { dapat } & \text { melihat. } \\ \mathrm{He} & \text { brightheart } & \text { even though } & \text { not } & \text { can } & \text { see. }\end{array}$

"He is intelligent even though he cannot see."

Other than the above mentioned idiom, the expression pencerahan ("brighten") has lately been used by speakers of Malay to mean other than its literal meaning. According to Kamus Dewan, the word pencerahan, in its literal sense, refers to "a change in physical properties, from dark to bright," (for example, menanggalkan kekotoran secara lembut untuk pencerahan kulit, mengurangkan melano ("to remove the dirt gently to brighten up the skin" $[\mathrm{PRPM}])$. However, the Malay language users have now extended the meaning of pencerahan to an abstract concept that means "to give intellectual insights." Kamus Online gives the following as an example:

\begin{tabular}{|c|c|c|c|c|c|c|}
\hline Mohon & $\begin{array}{l}\text { pencerahan } \\
\text { berkenaan }\end{array}$ & $\begin{array}{l}\text { dengan } \\
\text { penggunaan }\end{array}$ & $\begin{array}{l}\text { kata } \\
\text { setakat }\end{array}$ & $\begin{array}{l}\text { dan } \\
\text { sehingga, }\end{array}$ & $\begin{array}{l}\text { yang } \\
\text { manakah }\end{array}$ & betul? \\
\hline Please & $\begin{array}{l}\text { brighten } \\
\text { about }\end{array}$ & with use & $\begin{array}{l}\text { word } \\
\text { setakat }\end{array}$ & $\begin{array}{l}\text { and } \\
\text { sehingga }\end{array}$ & which one & correct? \\
\hline
\end{tabular}

The manifestation of conceptual metaphor KNOWLEDGE IS LIGHT is also observed in the following proverb: 
$\begin{array}{llll}\text { 9. Masuk } & \text { geronggang } & \text { bawa } & \text { pelita. } \\ \text { Enter } & \text { an opening } & \text { bring } & \text { lamp. }\end{array}$

"Bring a lamp when entering a (dark) opening in trees or boulders."

(Seri Bahasa n.d.)

"Geronggang" refers to a cave-like gap or a large opening in boulders and trees. In the proverb, pelita ("lamp") is used to refer to an individual who provides the source of light that brightens up the darkness of geronggang, who, in this case, is the more experienced (knowledgeable) person in a particular field. Apart from the conceptual metaphor KNOWLEDGE IS LIGHT, the other mechanism that is used in the proverb is the metonymy A LARGE OPENING IN BOULDERS OR TREES STANDS FOR A NEW VOCATION. The proverb above is dedicated to a person who is new to a vocation: that he should never hesitate to ask for guidance from those who are more experienced. Here, the metonymy LAMP STANDS FOR THE MORE KNOWLEDGEABLE PERSON is also used.

Light brightens up one's surrounding, and without light, everything around the person will become "dark." Since light and dark are complementary antonyms, the conceptual metaphor KNOWLEDGE IS LIGHT coexists with the conceptual metaphor NO KNOWLEDGE IS NO LIGHT in the Malay world. An example of an idiom that derives from the conceptual metaphor NO KNOWLEDGE IS NO LIGHT is gelap hati ("dark heart") which means "slow at understanding lessons." The idiom can be seen in the following:

$\begin{array}{rrrlll}\text { 10. Aku takdapat menentukan } & \begin{array}{l}\text { apakah aku gelaphati, } \\ \text { yang }\end{array} & \begin{array}{l}\text { atau dunia } \\ \text { ini }\end{array} & \begin{array}{l}\text { yang gelap } \\ \text { seluruhnya. }\end{array} \\ \text { I } & \text { cannot get } & \text { determine that dark heart } & \begin{array}{l}\text { or world } \\ \text { this }\end{array} & \begin{array}{l}\text { that dark } \\ \text { entirely. }\end{array}\end{array}$

"I cannot determine whether I am not clever or whether the world is entirely dark."

Up to this point, the manifestations of KNOWLEDGE as BIG and LIGHT in Malay figurative expressions have been presented. Because of the fact that KNOWLEDGE is so valuable and meaningful to the Malays, the Malays are encouraged to seek knowledge. The urge to do so is manifested in various linguistic expressions and these expressions are prevalent in the Malay language.

Analysis of the words that co-occur with ilmu and pengetahuan in the DBP Corpus suggests that there are some verbs that frequently collocate with them. This includes verbs that are derived from the Malay words tuntut, kejar, timba/cedok, dalami and turun, which means "to claim," "to pursue," "to (use a) bucket/to scoop," "to deepen" and "to go down," respectively. Although all of these verbs can be substituted with the verb memperoleh (i.e., "to seek/ acquire"), Malay speakers use these other verbs as alternatives to the verb in 
the expression memperoleh ilmu (i.e., "to acquire knowledge"). Why is there a need for such alternative verbs? Is it merely to add colour to the spoken and written language so that those involved in the conversation and writing will not be bored by the repetitive use of the word "memperoleh"? Are there other reasons that justify the use of these alternative verbs?

At a glance, the phrases tuntut ilmu, kejar ilmu, timba/cedok ilmu, dalami ilmu and turun ilmu give readers the impression that the phrases have no particular effect on its users, even to those who speak Malay as a first language. This is due to the fact that the phrases may have become "stock phrases" in the Malay speakers' lexicon and hence, are understood as "acquiring knowledge" or "seeking knowledge." An in-depth analysis of the phrases however, shows that the words that occur before the word ilmu can also give us an idea on how the concept of KNOWLEDGE is perceived and valued by the Malays.

Tuntut is a Malay verb that bears the meaning "to claim" in English. This word refers to "a particular action that demands, or asks for, or takes as one's own or one's due." Our experience tells us that "claims" are made by someone when he wants to regain ownership over a particular entity that belongs to him/her - especially when he/she is the rightful owner of the entity (i.e., the property owner) as in the following English examples: "to claim an estate by inheritance," "claim for damages," "insurance claim" and "claim the title." When the word tuntut collocates with ilmu, it indirectly gives the Malay language users the impression that all forms of ilmu belongs to everyone and that it is the very right of every individual to claim KNOWLEDGE from whoever is possessing it.

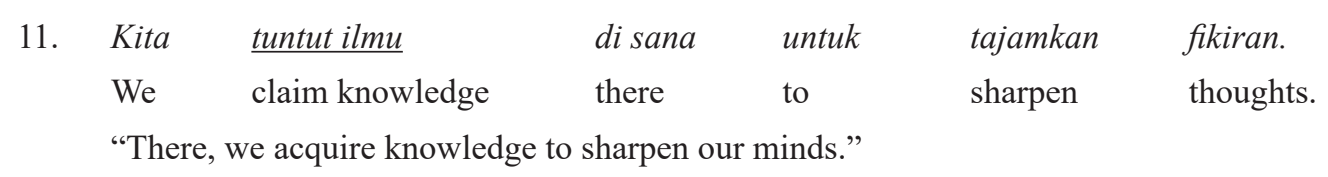

From the practical aspect of its use, despite the fact that tuntut can be interchangeably used with the word peroleh, tuntut brings along the idea that the process of "acquiring knowledge" has to go through a number of very specific and rigorous procedures; so rigorous that it sometimes requires the person who is making the "claims" to be proactive. The act of making a claim usually needs to be accompanied by a number of follow-ups that it sometimes takes place in an extended period of time. The process can be so long that the person who is making the "claims" may have the tendency to give up. All these experiences when making "claims" are visualised in the minds of the Malays when the word tuntut comes into picture; hence, when one is asked to tuntut ilmu, he/she is expected to be proactive, persistent and determined. 
Kejar, which can be translated into English as "to pursue," literally means "to follow in an effort to overtake or capture, chase." Similar to the verb tuntut, the verb kejar requires the doer to be proactive. The act of pursuing involves a lot of effort, with a high level of fitness; without a high fitness level, the individual will not be able to pursue his/her objectives over time. In mengejar ilmu, the root word kejar does not only reflect the efforts made by those who are trying to acquire knowledge; in fact, the word kejar also reflects the dynamic nature of KNOWLEDGE that is constantly moving and expanding. The Malays' view towards KNOWLEDGE is very relevant to the world today; a person will be left behind if he/she does not move in the same pace as knowledge does. One needs to continuously pursue knowledge in order to keep abreast with knowledge. An example of a sentence with the phrase mengejar ilmu in it is as follows:

$\begin{array}{lllll}\text { 12. Islam } & \text { sentiasa } & \text { menyeru } & \text { umatnya } & \text { mengejar ilmu. } \\ \text { Islam } & \text { always } & \text { call } & \text { its people } & \text { chase knowledge. }\end{array}$

"Islam always calls the Muslims to pursue knowledge."

Menimba and mencedok refer to the act of scooping something (water, or any other forms of liquid or fine objects) using a "bucket" (for menimba), and a "scoop" (for mencedok). Our past experience tells us that in performing the act of scooping water, for example, only the body of water that is the nearest to the surface of the water is scooped. The act of scooping requires some form of effort so that the container (i.e., the "bucket" or the "scoop") can be filled with water. Once the water is scooped, more effort is required to bring the container that is already filled up with water back to the hands of those who perform the act of scooping.

Although both activities, namely, menimba and mencedok seem similar in the form of their actions, the verbs used actually reflect the amount of effort a person puts in the process of seeking knowledge. Our encyclopaedic knowledge informs us that the size of a "bucket" is greater than the size of a "scoop." Due to the size difference between a "bucket" and a "scoop," the images that are visualised in the minds of the Malay speakers when these two verbs are mentioned are different. Menimba ilmu gives us the image of a person working with more effort than mencedok ilmu when he/she is acquiring knowledge. The results of these actions would naturally be different because the act of scooping using a bucket results in a larger volume of water in comparison to the act of scooping using a scoop. Hence, menimba ilmu creates the impression that the person who performs this action will be more 
knowledgeable than mencedok ilmu. An example of the use of menimba ilmu in Malay texts is:

$\begin{array}{llllll}\text { 13. Dia } & \text { suka } & \text { pergi } & \text { ke sekolah } & \text { kerana boleh } & \text { timba ilmu pengetahuan. } \\ \mathrm{He} & \text { like } & \text { go } & \text { to school } & \text { because can } & \text { scoop knowledge. }\end{array}$ "He likes to go to school because he can acquire knowledge."

Another interesting finding with regard to the use of menimba or mencedok with the noun ilmu is the fact that the concept of KNOWLEDGE is portrayed as "liquid" in both verbs. Our encyclopaedic knowledge of liquid tells us that liquid is fluid, has no fixed shapes, and that the shape of the liquid depends highly on the container that holds it. The use of the conceptual metaphors KNOWLEDGE IS LIQUID here is appropriate due to the fact that KNOWLEDGE changes as new discoveries are made. Apart from that, menimba and mencedok also give us the impression of that knowledge has "depth"; similar to my earlier discussion that KNOWLEDGE IS BIG. This is because, the act of "scooping," in normal circumstances, can only be done to a body of water/ liquid that is nearer to the surface.

The phrase dalami ilmu mentioned in Example 3 earlier also carries a meaning that goes beyond the size of knowledge. The expression suggests how KNOWLEDGE should be acquired. Dalami is defined as "the effort to understand something in greater details through research, etc., in order to transform something that is less perfect or less detailed to become more perfect or more detailed." An interesting fact about the verb dalami is that the presence of the Malay suffix $-i$ with the word dalam gives readers the impression that dalami is a process that can never be a complete process (infinity). When the verb dalami is used, it creates the impression that the bottom floor of the body of water (e.g., "the seabed") will never be found, no matter how long the person who wishes to acquire knowledge dives towards the floor of the sea. This again shows how large KNOWLEDGE is to the Malay speakers and that seeking knowledge must be made as a life-long process.

Earlier it was discussed that KNOWLEDGE is so important that it needs to be acquired. The Prophet [p.b.u.h.] also said: "Acquire knowledge and impart it to the people" (al-Tirmidhi, Hadith 107, islamawareness.net). To those who possess knowledge, it is important that he/she shares whatever knowledge he/she has with others. In the Malay language, other than the word ajar ("teach") or sampai ("convey") to describe how knowledge is transmitted, turun is also used to arrive at the same meaning. Turun is literally translated into English as "to bring down something from a higher position to a lower 
position." Metaphorically, turun ilmu refers to the act of a more knowledgable person transmitting his knowledge to another individual who hopes to acquire knowledge from him. This process is closely related to the hierarchical image schema that is supported by the conceptual metaphor THE PERSON WITH MORE KNOWLEDGE IS AT THE TOP. This is because of the amount of knowledge he/she possesses in relation to the person who hopes to acquire knowledge from him. What is interesting is the fact that the transmission of knowledge does not take place horizontally (i.e., not from left to right or from back to front). Instead, the transmission of knowledge takes place vertically in only one direction (i.e., from a higher position to a lower position). From the perspective of cognitive semantics, this visual imagery of the transmission of ilmu by speakers of Malay suggests how important KNOWLEDGE is to the Malays and this can be seen through the conceptual metaphor BETTER IS THOSE AT THE TOP. This also resonates my earlier discussion on the conceptual metaphor KNOWLEDGE IS BIG. This is because, for an object to be big, it must somehow be high as well (see Figure 1). This ICM also suggests the manner the Malays value those who possess knowledge: individuals who possess knowledge are placed highly in the Malay community and that it is their responsibilty to transmit the knowledge they possess to other individuals.

The importance of knowledge to be handed down from one generation to another is emphasised in the following hadith that is narrated by at-Tirmidhi. It is translated as the following: Usman ibn Affan r.a. narrated: Rasulullah [p.b.u.h] said: The best among you are those who learn the Qur'an and teach it (Sahih, sources al-Bukhari (no. 4639), Abu Dawud (no. 1240), al-Tirmdhi (no. 2832) and Ibn Majah (no. 207)) (Sunnah.com n.d.). An example of a sentence with the phrase turun ilmu is as follows:

$\begin{array}{llllll}\text { 14. Chef } & \text { Perancis } & \text { turun ilmu } & \text { gula } & \text { tarik } & \text { Langkawi. } \\ \text { Chef } & \text { French } & \text { bring down knowledge } & \text { sugar } & \text { pull } & \text { Langkawi. }\end{array}$

"A French chef shares knowledge on how to make the Langkawi sticky candy."

\section{DISCUSSION AND CONCLUSION}

The current study has presented the various ways how speakers of the Malay language manifest the concept of KNOWLEDGE. The findings suggest that Malays view KNOWLEDGE as something big and as a source of light. Because of this, knowledge has to be sought in a proactive manner and that seeking knowledge is a life-long process. 
This study also shows that although the analysis was carried on the Malay language, it is clear that the lives and the thoughts of the Malays in Malaysia are very much influenced by Islam. This is so because, as evident on the Terengganu Inscription Stone, Islam has come to the Malay Archipelago since as early as in 1303 CE (Salehuddin 2013); making Malay and Islam inseparable, as defined by the Federal Constitution (2010).

This study has shown that, to an extent, there is a similarity between Malay and English. The word "bright," for example, is one of the synonyms of the word "clever" (The Free Dictionary 2015). This suggests that the conceptual metaphor KNOWLEDGE IS LIGHT is also applied in the English language. This is seen in the following: "Some children are brighter in one subject than another" (The Free Dictionary 2015). The expression "broaden one's mind" is also used in the English language to refer to the effect of being knowledgeable (WordReference.com n.d.). This is seen in "They say that travel broadens the mind" (Cambridge Dictionary Online 2015). This suggests that the conceptual metaphor KNOWLEDGE IS BIG is also applicable in the English language.

This article shows that although Malay and English are two languages that are typologically not related, the expressions used and the cognitive mechanisms that underlie the expressions suggest that there are similarities in the ways ideas are processed by the two different speech communities. Some may argue that this may have resulted from some form of "borrowing" of words from one language to the other. However, this is not likely so because the manifestations of the concept of KNOWLEDGE in both languages are different. For example, the Malay translation for the expression "She is bright" is Dia itu terang hati and not "Dia itu terang (as the literal translation would suggest). In the English manifestation of KNOWLEDGE through the conceptual metaphor KNOWLEDGE IS LIGHT, the word "bright" does not modify any noun in the predicate; in the Malay language, however, the word terang ("bright") modifies another noun in the predicate, i.e., hati ("heart"). Hence, it can be said that the use of such a conceptual metaphor is not likely to be a result of "borrowing." This suggests that some conceptual metaphors are indeed universal in nature.

The findings of this study suggest that KNOWLEDGE can be discussed using the more general conceptual metaphor THE MIND IS THE BODY. However, despite the fact that the same general conceptual metaphor is used, the way the concept is manifested is language-specific. The different manifestations of the same conceptual metaphors suggest that the way human beings, despite speaking in different languages and living in different lifestyles, think is rather universal. This universal way of thinking is probably the factor that unites 
mankind all over the world, especially in distinguishing between what is good and what is bad for mankind. Future research on the manifestation of KNOWLEDGE in other languages can be conducted to further strengthen the claim made on universal conceptual metaphor.

\section{NOTES}

* Khazriyati Salehuddin $(\mathrm{PhD})$ is a psycholinguist and an Associate Professor at the Faculty of Social Sciences and Humanities, Universiti Kebangsaan Malaysia (UKM), Malaysia. She has a special interest in language and cognition and is currently heading several research projects related to the area, including a national-level grant, Qur'anic Memorisation Techniques: A Psycholinguistic Module for Non-Arabic-Speaking Malay Speakers. Khazriyati uses various methodologies in her research and has published several journal articles, book chapters and a monograph in the area. One of her works is published in South and Southeast Asian Psycholinguistics by Cambridge University Press and her single-authored book entitled Psikolinguistik: Penerokaan Minda Berlandaskan Bahasa (Psycholinguistics: A Language-based Exploration of the Mind) is published by UKM. She is currently the Head of Language and Cognition Research Cluster at her faculty. She teaches both undergraduate and postgraduate students for three different programmes namely English Language Studies, Linguistics and Teaching of English as a Second Language.

\section{REFERENCES}

Abdul Wahab, H. et al. 2016a. Analisis eufemisme kematian masyarakat Melayu Sarawak dari perspektif semantik kognitif. GEMA Online Journal of Language Studies 15 (2): 51-63.

. 2016b. Eufemisme pengurusan jenazah masyarakat Melayu Sarawak: Analisis semantik kognitif. Jurnal Bahasa 16 (1): 50-73.

Aida, A. and Nur Sakinah (eds.). 1996. Kamus Simpulan Bahasa Melayu. Kuala Lumpur: Al-Hidayah Publishers.

Andriessen, D. and Van Den Boom, M. 2009. In search of alternative metaphors for knowledge; Inspiration from symbolism. Electronic Journal of Knowledge Management 7 (4): 397-404.

Al-Quran.

Bahasa Melayu SPM. 2012. http://subrato403.blogspot.com/2012/10/peribahasa-dancogan-kata-untuk-tema.html, 27 Oktober (accessed 29 October 2016).

Black, M. 1972. Models and metaphors: Studies in language and philosophy. London: Cornell University Press. 
Boroditsky, L. 2012. How the languages we speak shape the ways we think. In The Cambridge handbook of psycholinguistics, eds. Spivey, M. J., McRae, K. and Joanisse, M. C., 615-632. Cambridge: Cambridge University Press, https://doi. org/10.1017/CBO9781139029377.042.

Cambridge Dictionaries Online. 2015. http://dictionary.cambridge.org/dictionary/british (accessed 20 October 2016).

Dewan Bahasa \& Pustaka. 2000. Kamus Dewan, 3rd ed. Kuala Lumpur: Dewan Bahasa \& Pustaka.

Duas.org. n. d. Duas for students. http://www.duas.org/student.htm (accessed 29 October 2016).

Everymuslim.net. n. d. Dua to read after the recitation of the Quran. http://www. everymuslim.co.za/index.php/articles-menu/duas-menu/490-dua-to-read-after-therecitation-of-the-quran) (accessed 29 October 2016).

Gibbs, R. W. and Colston, H. L. 2012. Interpreting figurative meaning. Cambridge: Cambridge University Press, https://doi.org/10.1017/CBO9781139168779.

Goddard, C. 2008. Contrastive semantics and cultural psychology: English heart vs Malay hati. In Culture, body, and language: Conceptualizations of internal body organs across cultures and languages, eds. Sharifian, F., Dirven, R., Yu, N. and Niemeier, S., 75-102. Berlin: Mouton de Gruyter.

Islamawareness.net. n. d. http://www.islamawareness.net/Knowledge/knowledge article0001.html (accessed 29 October 2016).

Kamus Online. n. d. http://prpm.dbp.gov.my/Search.aspx?k=pencerahan (accessed 29 October 2016).

Kövecses, Z. 2007. Metaphor in culture: Universality and variation. Cambridge: Cambridge University Press.

Kövecses, Z. and Szabó, P. 1996. Idioms: A view from cognitive semantics. Applied Linguistics 17 (3): 326-335, https://doi.org/10.1093/applin/17.3.326.

Lakoff, G. and Johnson, M. 1980. Metaphors we live by. Chicago: University of Chicago.

Pusat Rujukan Persuratan Melayu. 2008. http://prpm.dbp.gov.my/ (accessed 29 October 2016).

Salehuddin, K. and Maros, M. 2004. 'Dikecilkan hati si panas darah' dari perspektif semantik kognitif. Jurnal Bahasa Jendela Alam 3: 367-377.

Salehuddin, K. 2000. Mekanisme kognitif dalam simpulan bahasa kuasa/kawalan. Jurnal Dewan Bahasa 44 (12): 1222-1238.

2001. Falling for cognitive semantics. In Writings in applied linguistics in the Malaysian context: A festschrift in honor of Abdul Aziz Idris, eds. Maros, M. and Quah, C. K., 46-52. Bangi: Faculty of Language Studies and Linguistics, UKM. 2007. Metafora Melayu dalam mendidik anak: Analisis semantic kognitif. In Linguistik: Teori dan Aplikasi, eds. Jalaluddin, N. H, Abdullah, I. H. and Aman, I., 136-151. Bangi: Penerbit UKM.

2013. Arabic script of written Malay: Innovative transformations towards a less complex reading process. Pertanika: Journal of Social Sciences and Humanities 21 (S): 63-76.

Senilukis101. n. d. Seni afektif psikomotor kognitif. https://senilukis101.wordpress.com/ koleksi/poster/ (accessed 29 October 2016). 
Seri Bahasa. n. d. Seri Bahasa: Sirih pinang warisan budaya Melayu. http://www.seribahasa. com (accessed 29 October 2016).

Sunnah.com. n. d. http://sunnah.com/bukhari/66/49 (accessed 29 October 2016).

Sweetser, E. 1990. From etymology to pragmatics: Metaphorical and cultural aspects of semantic structure. Cambridge: Cambridge University Press, https://doi. org/10.1017/CBO9780511620904.

Taverniers, M. 2006. Grammatical metaphor and lexical metaphor: Different perspectives on semantic variation. Neophilologus 90 (2): 321-332, https://doi.org/10.1007/ s11061-005-0531-y.

The Federal Constitution. 2010. Kuala Lumpur: The Commissioner of law revision, Malaysia (as at 1 November 2010). http://www.agc.gov.my/agcportal/uploads/files/ Publications/FC/Federal\%20Consti\%20(BI\%20text).pdf.

The Free Dictionary. 2003. http://www.thefreedictionary.com/ (accessed 20 October 2016). WordReference.com. n. d. http://www.wordreference.com/ (accessed 20 October 2016). 